Acta vet. scand. $1977,18,138-139$.

Brief Communication

\title{
OCCURRENCE OF GAFFKAEMIA IN LOBSTERS IN NORWAY
}

Gaffkaemia is a bacterial disease which causes periodic, lethal epizootics in holding facilities for live American (Homarus americanus) and European (Homarus vulgaris) lobsters (Snieszko \& Taylor 1947, Roskam 1957). Gaffkaemia, with the causative agent Aerococcus viridans, has been diagnosed in many countries in Europe and elsewhere. Roskam $(1957,1958)$ reported the disease in lobsters imported to the Netherlands from Norway. In Norway, however, the disease has never before been reported, though an experiment has shown that gaffkaemia could be induced in lobsters from a Norwegian area with injections of the A.T.C.C. type strain no. 10400 of the causative agent (Møllerud 1971).

An outbreak of the disease in a lobster pound on the Norwegian west coast, believed to be the first incidence of gaffkaemia reported from Norway, is described here.

Ten lobsters (Homarus americanus) were received for examination. The lobsters (weighing 400-500 g) originated from a pound which in September had imported 500 lobsters from Canada (St. Lawrence area). During the first week after arrival in Norway, about $23 \%$ of the lobsters died. Because the high mortality rate was thought to be due to water pollution in the area, the lobsters were moved to a pound around Kvits $\varnothing \mathrm{y}$ near Stavanger, where they were held in facilities together with lobsters captured in Norwegian waters. The seawater temperature ranged from 11 to $14^{\circ} \mathrm{C}$. Mortality among the Canadian lobsters, however, still continued. According to the owner's information, the number of imported lobsters was reduced by about $60 \%$ during the following six weeks.

The affected lobsters became weak, died without external symptoms, and necropsy showed no macroscopic pathological findings. For bacteriological examination blood agar plates with $5 \%$ defibrinated goat blood and $0.5 \%$ sodium chloride, and trypticase soy agar plates, were inoculated and incubated aerobically and anaerobically for $48 \mathrm{hrs}$. at $20^{\circ} \mathrm{C}$. Isolates obtained in pure cultures from heart, digestive gland, green gland and muscle tissue were identified, according to Bergey's Manual (1974) and by comparing their cultural and biochemical properties with the ATCC type strain no. 10400, as A. viridans. 
A. viridans could not be isolated from healthy, killed Canadian or Nordwegian lobsters from the same pound.

The large chelae of the Canadian lobsters were immobilized by wedging them closed with one-inch long wooden pegs, producing wounds, while the large chelae of the Norwegian lobsters were closed with rubber bands, which gave no traumatic lesions. The tips of the pegs from nine healthy Canadian lobsters were examined bacteriologically, and from five of these nine, A. viridans was isolated. We therefore believe that the wounds produced by the pegs are effective portals for the entry of the pathogen agent. These findings are in good agreement with the observations of Steward et al. (1969). They found infection $24 \mathrm{hrs}$. after insertion of the pegs and suggested that the commercial use of plugs for closing chelae could be a major contributing factor to massive outbreaks of gaffkaemia.

Further studies concerning the route of infection and the occurrence of the bacterium in Norwegian lobster parks are recommended.

T. Håstein \& S. O. Roald

National Veterinary Institute, Oslo, Norway.

\section{B. Kjos-Hansen \& K. Staveland}

The City Public Health Laboratory, Stavanger, Norway.

\section{REFERENCES}

Bergey's Manual of Determinative Bacteriology. R. E. Buchanan \& N. E. Gibbons, eds. Eighth Ed. The Williams \& Wilkins Company, Baltimore 1974.

Møllerud, E. E.: On the internal bacterial flora of the European lobster, Homarus vulgaris, and its susceptibility to gaffkaemia. Int. Counc. Explor. Sea. C. M. 1971/K:21. Shellfish and Benthos Comm. 5 pp. (Mimeogr.).

Roskam, R. T.: Gaffkaemia, a contagious disease in Homarus vulgaris. Int. Counc. Explor. Sea. C. M. 1957. Shellfish Comm.

Roskam, R. T.: A short note on gaffkaemia in lobsters. Int. Counc. Explor. Sea. C. M. 1958. Shellfish Comm. No. 59.

Snieszko, S. F. \& C. C. Taylor: A bacterial disease of the lobster (Homarus americanus). Science 1947, 105, 500-501.

Steward, J. E., A. Dockrill \& J. W. Cornick: Effectiveness of the integument and gastric fluid as barriers against transmission of Gaffkya homari to the lobster Homarus americanus. J. Fish. Res. Bd Can. 1969, 26, 1-14.

(Received December 30, 1976).

Reprints may be requested from: Tore Håstein, National Veterinary Institute, Postboks 8156, Oslo Dep., Oslo 1, Norway. 